\title{
THROUGH DARK AND MYSTERIOUS PATHS. EARLY MODERN SCIENCE AND THE SEARCH FOR THE ORIGIN OF SPRINGS FROM THE $16^{\text {TH }}$ TO THE $18^{\text {TH }}$ CENTURIES
}

\author{
FRANCESCO LUZZINI \\ University of Oklahoma, University Libraries \\ 401 West Brooks Street, Bizzell Memorial Library - 73019 Norman (OK), USA \\ francesco_luzzini@yahoo.com / fluzzini@ou.edu
}

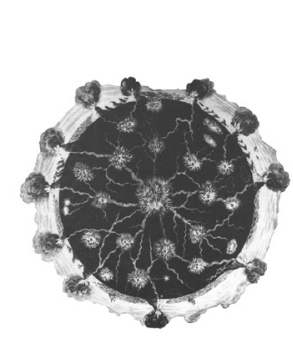

Earth Sciences History

Vol. 34, No. 2, 2015 pp. 169-189

\section{ABSTRACT}

\begin{abstract}
Since its first attempts to understand natural phenomena, early modern science devoted great attention to the problematic issue of the origin of springs. This essay examines the lively debate that emerged from the studies on fresh water during the years spanning from the mid-sixteenth century to the early eighteenth. By focusing on the interpretations advanced by several authors (including lesser known, but nonetheless important figures such as Mario Bettini, Edward Barlow, and Diacinto Cestoni), and by introducing Antonio Vallisneri's Primi itineris specimen, an unpublished manuscript which reveals significant insights into the hydrogeological debate, a new analysis is provided of the heterogeneous factors which influenced the path of natural philosophy towards the comprehension of the water cycle. The conclusion suggests how a reconsideration of the intricate backgrounds underlying many scientific debates and concepts could play a critical role in solving a still controversial issue: science's need for a history of science.
\end{abstract}

Keywords: Early modern period, water cycle, natural philosophy, hydrogeology, Republic of Letters

doi: $10.17704 / 1944-6187-34.2 .169$

\section{COMMON SENSE}

It may seem weird to us, or curious at least, that one of the most critical resources for human societies had to wait for such a long time before the processes related to its origin were effectively understood. This perception may be even more sharpened by the simple fact that, among all the scientific concepts which are taught in schools, the water cycle has proven to be one of the most resistant to the injuries of time on memory.

The success of this notion is likely related to its clarity, which is so suitable to (present) common sense: water evaporates from oceans, lakes, streams, and living organisms; vapor condenses in clouds; clouds originate precipitation as rain, snow, and hail, which in turn, by runoff, nourish glaciers, aquifers, streams, rivers, lakes, seas, oceans; and so on, over and over again. Nevertheless, the apparent and praiseworthy simplicity of this concept was not easy to comprehend initially. Along history's path, common sense has proven to be an insidious partner for human judgment. The hydrologic cycle is no exception, for it can be considered as a simple process only at a first glance, and from our privileged (if however partial) point of view. Indeed, it involves so many concurrent chemical and physical factors that its comprehension was a major challenge for generations of natural philosophers from the sixteenth century to the first decades of the eighteenth. Not by chance, since early modern science made its first steps in the study of natural phenomena, it devoted great and persistent attention to the problematic issue of the origin of springs and fresh water.

As may be presumed, this interest was not aroused just by a mere philosophical curiosity. Water management was - as it is now - a crucial topic for communities and governments. Droughts and floods often meant the difference between wealth and misery, civic stability and insurrection, abundance and famine, health and disease, and, therefore, between life and death, with all the related social, economic and political consequences. It is no wonder, then, that such a vital resource soon became a subject of investigation and controversy in the early modern period by a number of scholars and technicians all over Europe, whose studies were influenced by 
different cultural, philosophical, religious and scientific values and backgrounds. The newborn experimental method was still largely and fiercely debated, both by its advocates and detractors. Yet, it gave an undeniable and powerful impulse to the already existing studies of nature. New explorations were performed on and into the mountains, in caves, and pits; miners, apothecaries, and technicians disclosed their knowledge to those enlightened scholars, academics, inquiring noblemen and clerics who were not afraid to soil their hands, clothes, and wigs just to catch some sparks of truth in the bowels of the Earth. But a long time would pass before a clear, proven theory on the origin of springs emerged. ${ }^{1}$ Natural philosophers puzzled over the apparently unsolvable mystery of the continuous refilling of streams and rivers, and tried to ascertain the existence of other phenomena which, together with evaporation, could raise sea water up the mountains and transform it into fresh water. And in dealing with this difficult challenge, the "new science' was not alone.

\section{ECLECTICISM}

It is by now widely acknowledged that early modern experimentalism and philosophical or religious interpretations of nature were not sharply separated by insurmountable ideological barriers (nor are they now, despite the magniloquent claims still coming from too many ardent supporters of each side). Far from being mutually exclusive, these facets of human knowledge coexisted and interacted, and in many cases their reciprocal influence was a common trait of European scholars, regardless of whether they would be considered by conventional historiography - or would consider themselves - as 'solid scientists' or 'speculative savants'. Already in the sixteenth century, not a few of the arguments advanced by Aristotelian or Neoplatonic and Hermetic authors in order to explain the origin of fresh water relied on field research; and indeed, field research often persuaded them that rains and snows were not enough to replenish springs and rivers. Hence came the idea that hidden channels existed connecting the oceans to the earth, allowing sea water to rise up the mountains and to lose its salt by means of filtration through rock layers, or by condensation of vapor inside secret caves (the so-called theory of 'alembics', that would find its greatest champion in Descartes), ${ }^{3}$ or both.

Undoubtedly, a major role in shaping these theories was due to the imposing legacy of the classical tradition. Greek and Roman authors such as Thales, Anaxagoras, Diogenes, Aristotle, Plato, Theophrastus, Vitruvius, Lucretius, Seneca, Pliny the Elder, and not a few other 'ancients' paid attention to the study of springs and to the relationship between precipitation and the recharge of aquifers, with various and, of course, mutually influencing results. ${ }^{4}$ Providing a more or less detailed summary of these heterogeneous interpretations was an inescapable duty for any early modern natural philosopher who intended to deal with the study of waters-a duty which in many treatises was typically paid within the first pages or chapters.

Another, essential stream of knowledge came from the medieval elaborations of both the Aristotelian and Platonic thoughts, which in the Renaissance intereacted with a wide spectrum of esoteric traditions. Aristotelianism, as well as Neoplatonic and Hermetic doctrines, tended to recognize in water and in the supposed subterranean passages the macroscopic analogy of human blood and vessels. Subterranean heat and other geological and atmospheric phenomena,

\footnotetext{
On this topic, see Magnaghi 1911; Masini 1931; Dooge 1974; Morello 1979; Baldini 1981; Maffioli 1994; Dooge 2001; Vaccari 2001; Luzzini 2008; Luzzini 2010; Maffioli 2010; Luzzini 2011a; Luzzini 2011b; Luzzini 2011c; Luzzini 2012a; Luzzini 2012b; Luzzini 2013a; Luzzini 2013b; Luzzini 2013c; Luzzini 2013d; Luzzini 2014.

With particular respect to the earth sciences, see Rudwick 1972, pp. 10, 16-26, 34-93, 133-139, 168-175, 189, 242; Oldroyd 1974; Rappaport 1978; Albritton 1980; Dean 1981; Dean 1985; Gould 1987; Wilcox 1987; Guntau 1989; Young 1995; Cohn 1996; Bettini 1997; Rappaport 1997, pp. 57, 106-107, 109-110, 119-122, 125-128, 130-135, 154, 169, 183-187, 219, 238; Harrison 1998; Gould 2004; Magruder 2006; Dal Prete 2007, pp. 73-102; Magruder 2008; Van der Meer and Mandelbrote 2008; Kölbl-Ebert 2009; Rosenberg 2009; Luzzini 2013 d.

Descartes 1644, pp. 228-231. On this topic, see Luzzini 2008, pp. 366-367; Luzzini 2010, pp. 98-101, 117-118; Luzzini 2011c, pp 350-353; Luzzini 2012b; Luzzini 2013a; Luzzini 2013d, pp. 98, 109-114, 116, 120-123, 129$131,141,143-144,153,184$.
}

$4 \quad$ For an overview on this topic, see Barton 2015. 
consequently, were considered as macroscopic counterparts of human metabolic processes. Such was the evocative power of these concepts that they spread across religious, cultural, and chronological boundaries, pervading - to varying degrees and with extremely heterogeneous outcomes - the research of a number of authors such as Leonardo (1452-1519), Georgius Agricola (1494-1555), Girolamo Cardano (1501-1576), Robert Fludd (1574-1637), Pierre-Jean Fabre (1588-1658), Jan Baptist Van Helmont (1579-1644), of Lutheran scholars such as Johann Johachim Becher (1635-1682) and Johannes Herbinius (1632-1676), of important Jesuits such as Mario Bettini (1584-1657), Gaspar Schott (1608-1666), and, of course, Athanasius Kircher (1602-1680), and many more. ${ }^{5}$ But it is worth noting that not a few of these authors firmly thought rain, snow, and glaciers to be at least essential causes of the origin of springs, if not the main or the only ones. Included among these were Leonardo, Cardano, Van Helmont, Herbinius, Schott, and Kircher (see Figure 1), just to mention some of them. And there was the peculiar case of the French physician and alchemist Pierre-Jean Fabre, who, in his Hydrographum spagirycum, fully supported the meteoric origin of springs by considering precipitation as the result of many 'seminal principles' mixed and transformed into rain, snow, hail, dew, fog, and fountains, by an ubiquitous and permeating 'natural spirit':

So all springs, and fountains of water, come and flow from that spirit; not from the sea, not from the air, nor from any other natural element, but only from that spirit, that produces all the vapors and steams from which rain, dew, snow, hail, daily irrigate the Earth (Fabre 1639, p. 14). ${ }^{6}$

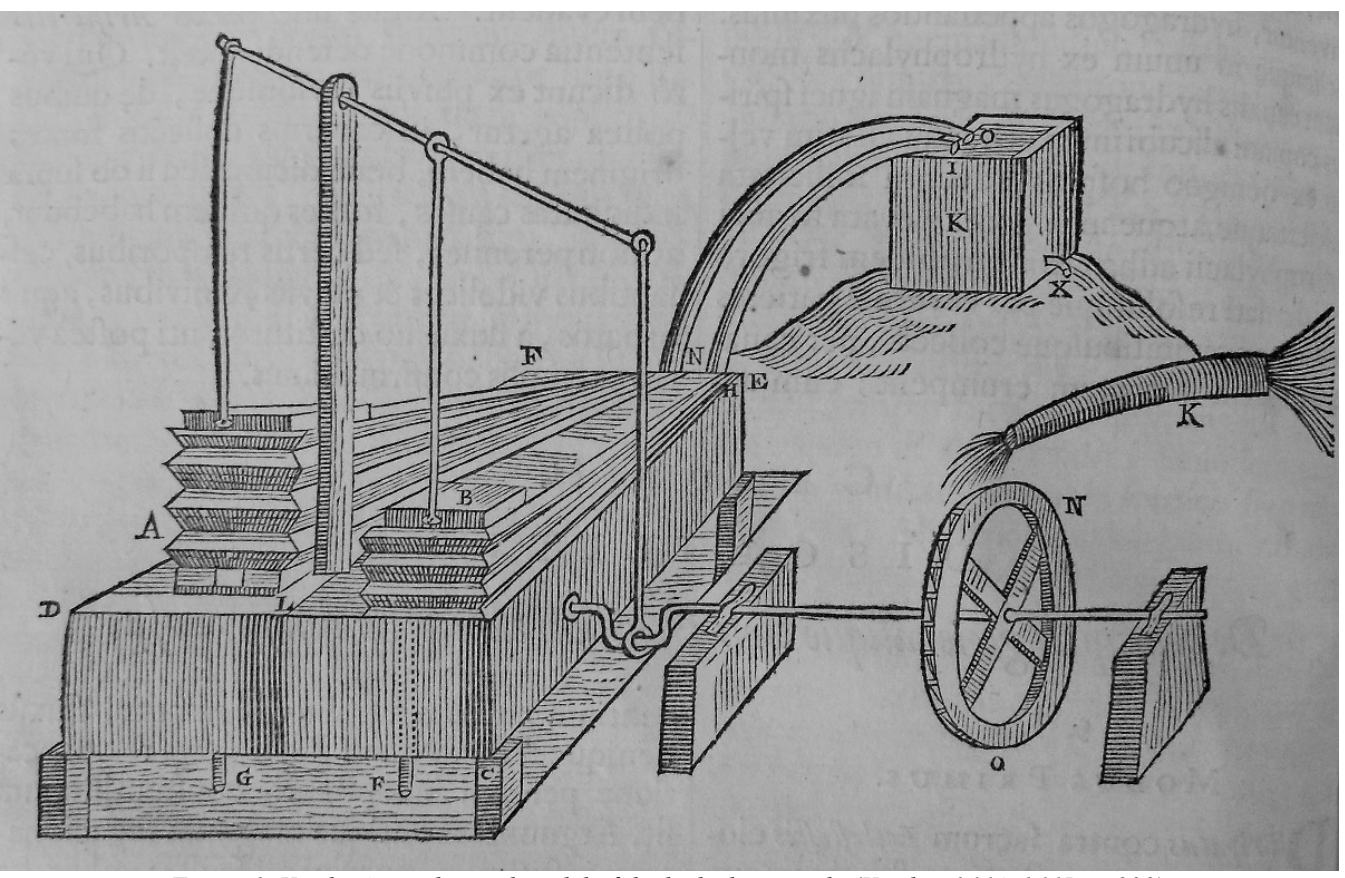

Figure 1. Kircher's mechanical model of the hydrologic cycle (Kircher 1664-1665, p. 230).

Conversely, still in the seventeenth and in the early eighteenth centuries, many renowned experimentalists - as, for example, Edmond Halley (1656-1742), Robert Plot (1640-1696),

Leonardo Da Vinci, Codex Atlanticus. Veneranda Biblioteca Ambrosiana, Milan, ff. 433, 468; Agricola 1546; Cardano 1550, pp. 10-11, 76; Cardano 1557, pp. 33-44; Fludd 1617, pp. 199-200; Fabre 1639, pp. 1-15; Bettini 1642, pp. 24-25; Kircher 1660, pp. 528-553; Schott 1663, pp. 131-354; Kircher 1664-1665, pp. 226-233; Becher 1669, pp. 51-80; Herbinius 1678, pp. 69, 73-74; Van Helmont 1682, pp. 646-648.

6 Concludamus ergo fontes omnes, et aquarum scaturigines, ab spiritu illo provenire et dimanare, non ex mari, non ex aere, nec ex ulla alia re naturali, quam ex solo illo spiritu, qui vapores, et halitus producit omnes, ex quibus, pluvia, ros, nix, grando, quotidie fiunt ad irrigandam terram. 
Bernardino Ramazzini (1633-1714), Jacques Rohault (1618-1672), and Luigi Ferdinando Marsili (1658-1730) - partially supported the theories of 'alembics' and/or of the filtration of sea water through rock strata. In their opinions, which were based on careful measurements and observations, meteoric water alone was insufficient to replenish fresh water supplies (Rohault 1671, pp. 249-252 ; Plot 1685 ; Plot 1686, pp. 51-52, 74-75, 88 ; Halley 1687; Halley 1691; Ramazzini 1691, pp. 29-39, 53-64; Marsili 1725, p. 13 ; Marsili 1930, p. 57). ${ }^{7}$ So wrote Halley, in the XVII volume of the Philosophical Transactions:

Those vapours therefore that are raised copiously in the sea, and by the winds are carried over the low land to those ridges of mountains, are there compelled by the stream of the air to mount up with it to the tops of the mountains, where the water presently precipitates, gleeting down by the crannies of the stones; and part of the vapour entering into the caverns of the hills, the water thereof gathers as in an alembick into the basons of stone it finds, which being once filled, all the overplus of water that comes thither runs over by the lowest place, and breaking out by the sides of the hills, forms single springs. Many of these running down by the valleys or guts between the ridges of the hills, and coming to unite form little rivulets or brooks: many of these again meeting in one common valley and gaining the plain ground, being grown less rapid become a river: and many of these being united in one common channel make such streams as the Rhine, the Rhone, the Danube, which latter one would hardly think the collection of water condensed out of vapour, unless we consider how vast a tract of ground that river drains, and that it is the sum of all those springs which break out on the South side of the Carpathian Mountains, and on the North side of the immense ridge of the Alps, which is one continued chain of mountains from Switzerland to the Black Sea. And it may almost pass for a rule, that the magnitude of a river, or the quantity of water it evacuates, is proportionable to the length and height of the ridges from whence its fountains arise. '. . '

Thus is one part of the vapours blown upon the land returned by the rivers into the sea, from whence they came; another part by the cool of the night falls in dews, or else in rains, again into the sea before it reaches the land, which is by much the greatest part of the whole vapour, because of the great extent of the Ocean, which the motion of the winds does not traverse in a very long space of time. And this is the reason why the rivers do not return so much into the Mediterranean as is extracted in vapour. A third part falls on the lower lands, and is the pabulum of plants, where yet it does not rest, but is again exhaled in vapour by the action of the sun, and is either carried by the winds to the sea to fall in rain or dew there, or else to the mountains to be there turned into springs; and though this does not immediately come to pass, yet after several vicissitudes of rising in vapour and falling in rain or dews, each particle of the water is at length returned to the sea from whence it came. Add to this that the rain-waters, after the Earth is fully sated with moisture, does by the valleys or lower parts of the Earth find its way into the rivers, and so is compendiously sent back to the sea. After this manner is the circulation performed, and I doubt not but this hypothesis is more reasonable than that of those who derive all springs from the rain waters, which yet are perpetual and without diminution, even when no rain falls for a long space of time. ' . . ' This, if we may allow final causes, seems to be the design of the hills, that their ridges being placed through the midst of the continents, might serve as it were for alembicks to distil fresh water for the use of man and beast, and their heights to give a descent to those streams to run gently, like so many veins of the Macrocosm, to be the more beneficial to the Creation (Halley 1691, pp. 471-473). ${ }^{8}$

This eclectic, promiscuous context clearly contrasts the commonly held, but outdated belief in a linear and gradual history of science, which pits 'true' scientists against reactionary enemies, the latter being typically identified as philosophers, priests, alchemists, astrologer, etc. Actually, the early modern scientific and intellectual debate was much more intricate (and, to our pleasure, intriguing). It was from this turbulent, lively background that the new science of hydrogeology emerged, gaining knowledge from many different disciplines such as physics, hydraulics, mathematics, meteorology, mineralogy, mining technology, engineering, chemistry (but also from

On Marsili's theories, see Vaccari 2001; Vai 2006.

Just a year later, Halley's uncertain allusion to the possibility of "allowing final causes" received a sharp-though benevolent - comment from John Ray: "And why may we not? What needs this hesitancy and dubitation in a thing that is clear?" (Ray 1692, p. 253). 
philosophy, theology, alchemy, pottery, agronomy), which-just like streams merging into a single river-contributed to the comprehension of the hydrologic cycle. And in this process, of course, the biblical benchmark could not be excluded by any means.

\section{RELIGION}

Hitherto from philosophy and profane history having made it probable at least that few springs come from rains, snows, etc., and manifest that many of them, if not all that are considerable do come from the sea through subterraneous passages, let us next add (what should put all out of doubt with a Christian reader) the constant uniform concurrence, of Holy Writ; where they are expressly called the springs of the sea, and the fountains of the deep; the whole circulation whereof is more fully declared by the Wise-Man in Ecclesiastes '. . . W Which text, if well considered, seems to include a problem, and in the latter part, the Wise-Man's answer; the question in the first part being, how it comes to pass, that all the rivers running into the sea, yet the sea is not full? To which he plainly answers: unto the place from whence the rivers come, thither they return again. I.e. that there is a perpetual motion or circulation of the waters through the globe of the Earth, and that the sea sends as much forth again for the supply of the rivers as it received from them; which manifestly shews us why the sea is not full. I know that Mr. Ray would have this performed by the superior circulation through the clouds, and not by subterraneous passages, that is, that the sun exhales water out of the sea, which being poured down again from the clouds upon the Earth from part thereof falling upon and soaking into the higher grounds, he would have the springs and rivers arise; and that this way, whence the rivers come, they should return again. But I can by no means allow this for a solution, since it manifestly infringes the whole analogy of the Scriptures (Plot 1686, pp. 74-75).

So wrote a concerned Robert Plot in his Natural History of Stafford-Shire, referring to a biblical passage from the book of Ecclesiastes, Chapter 1, verse 7: "All the rivers run into the sea, yet the sea is not full; unto the place from which the rivers come, thither they return again". At least up to the middle of the eighteenth century, these few words constituted an unavoidable hurdle for every scholar, Catholic and Protestant alike, who intended to deal with the problem of the origin of springs. Similarly to what happened with other thorny issues, such as the Copernican theory or the debates on fossils, on diluvialism, and on deep time, in many cases the attempts to reconcile faith with facts involved looser interpretations of the Holy Text. But other authors were determined to take the biblical account literally, leaving little or no room for milder options. ${ }^{9}$ Plot was one of them - and in order to explain the origin of a part of fresh water without detriment to the Ecclesiastes, he followed Aristotle (in Meteorology, I: 13) in supposing that sea water would rise through hidden passages up the mountains. This phenomenon was caused both by subterranean heat and pressure, as - according to him - the average altitude of land masses was below the sea level (Plot 1685, pp. 144-145, 154, 171-173). Ironically, and quite significantly, the author whose theories 'infringed the Scriptures' was the clergyman John Ray (1627-1705), who answered Plot in his Miscellaneous Discourses Concerning the Dissolution and Changes of the World:

'. . ' I can by no means assent to the learned Doctor Plot (if I understand him aright) that the valleys are as much below the surface of the sea, as mountains are above it. For how then could rivers descend down to the sea through those valleys? The sea would rather run into them, and make sinuses; or else, if they were enclosed, the water would stagnate there, and make pools. If this be done by way of filtration (which seems to be the most likely means of raising the water) I do not see, but these filtres may suck up the whole Ocean; and, if apertures and out-lets large enough were made, powre it out upon the Earth in no long time. But I cannot be fully reconciled to this opinion, though it hath great advocates, especially the fore-mentioned very learned and ingenious person Doctor Robert Plot. I acknowledge subterraneous waters: I grant a confluence and communication of seas by

See Rudwick 1972, pp. 10, 16-26, 34-93, 133-139, 168-175, 189, 242; Oldroyd 1974; Rappaport 1978; Albritton 1980; Dean 1981; Dean 1985; Gould 1987; Wilcox 1987; Guntau 1989; Young 1995; Cohn 1996; Bettini 1997; Rappaport 1997, pp. 57, 106-107, 109-110, 119-122, 125-128, 130-135, 154, 169, 183-187, 219, 238; Harrison 1998; Gould 2004; Magruder 2006; Dal Prete 2007, pp. 73-102; Magruder 2008; Van der Meer and Mandelbrote 2008; Kölbl-Ebert 2009; Rosenberg 2009; Luzzini 2013d. See also https://vimeo.com/46769954. 


\section{EARLY MODERN SCIENCE AND THE ORIGIN OF SPRINGS}

underground channels and passages. But this inferiour constant circulation and perpetual motion of water seems to me not yet sufficiently proved and made out. I think that the patrons and abettors of this opinion, have not satisfactorily demonstrated, how it is, or can be performed (Ray 1692, pp. 7071).

Besides, Ray did not "peremptorily affirm, that all fountains do proceed from rain". Torrid climates could require complementary means to replenish fresh water supplies.

Therefore, whenever in this work I have assigned rain to be a sufficient or only cause of springs and rivers, I would not be understood to exclude, but to comprehend therein mists and vapours; which I grant to have some interest in the production of them, even in temperate and cold regions; and a very considerable one in hot. Though I cannot be persuaded, that even there they are the sole cause of springs, for that there fall such plentiful and long continuing rains, both in the East and West Indies in the summer months: which must needs contribute something to their original (Ray 1692, pp. 73$74,252-253)$.

The thesis of a compound origin of fresh water and of hidden passages - dark and mysterious paths - connecting oceans and mountains, as we have seen, was not an exception among early modern scholars. Its persistence to the midpoint of the eighteenth century, and probably even later, had scientific, philosophical, and religious causes. On one hand, it attempted to justify many apparent measurement deficits in hydrologic balances, which could not be otherwise explained (not, at least, until further field research, experiments, and measurements succeeded in proving the exclusive meteoric origin of springs). On the other hand, it was a magnificent way to harmonize in a single theory Aristotelian, Neoplatonic and Hermetic traditions, new philosophical doctrines (such as Cartesianism), ${ }^{10}$ experimental data, and religious orthodoxy. And within the Catholic context, the most efficient and fascinating efforts in this direction came from the members of the Society of Jesus.

It is widely understood that despite the monolithic, almost mythological reputation surrounding these relentless defenders of the Counter-Reformation, many members of this (actually complex and heterogeneous) order never considered science as an enemy. Rather, it was to them a new battlefield on which heresy, that was the true enemy, must be fought. Since the sixteenth century, Jesuit colleges all over Europe had become centers of excellence for several disciplines such as mathematics, astronomy, hydraulics and mechanics; ${ }^{11}$ and sure enough, this made Jesuit scholars the most fierce opponents of any potentially heretical scientific interpretation. Still, they provided an astounding number of significant contributions to the development of natural and physical sciences, and often their studies interacted with the very Galilean theories they opposed (as in the cases, for example, of Honoré Fabri (1607-1688) and Claude François Milliet Dechales (1621-1678), whose treatises on physics and hydraulics, though anti-Copernican, were deeply influenced by Galileo's and Torricelli's studies on motion and pressure (Fabri 1665; Milliet Dechales 1674).

Whether secular or religious, it is hard not to be charmed by these works, that often involved a heroic confrontation between a passionate faith and first-rate technical, scientific and philosophical knowledges. In Jesuit authors such as Kircher and Schott, Neoplatonic and Hermetic beliefs coexisted with field research and experimental practice, leading to intriguing results. In the Mundus subterraneus (Kircher 1664-1665), as much as in the Anatomia physicohydrostatica fontium ac fluminum (Schott 1663), the whole Earth-or "Geocosmus" - is studied as a living organism, in which each part is interconnected with the others (and before dismissing this approach as infertile or antiquated, just think of such trendy modern notions as 'ecosystem' or 'cybernetics', and of the great influence of these concepts, though often misunderstood, on

10 And especially the influential Cartesian theory of 'alembics' (Decartes 1644, pp. 228-231).

11 For comprehensive studies on this topic, see Baldini 1980, pp. 480, 513-526; Rurale 1992; Maffioli 1994, pp. 5, 10, 24, 30-31, 33, 44, 51, 54, 71, 133, 169, 186-187, 321; Generali 1996; Battistini 2000; Borgato 2002; Feingold 2003; O' Malley et al. 2006; Maffioli 2010, pp. 4-6, 151-152, 161, 199, 232-240, 258, 264, 274-275, 331. 
popular culture). ${ }^{12}$ Like in the human body, different kinds of vital fluids flow through the planet. Springs, aquifers, floods, tides, volcanoes, earthquakes, winds, rains, and other natural phenomena are the results of the interaction between these circulatory systems, called "fire networks" (pyrophylacia), "air networks" (aerophylacia), and "water networks" (hydrophylacia). Kircher acknowledges evaporation as a means to replenish springs and rivers. But the hydrophylacia are the main causes of this process - they connect the sea to the mountains, allowing the water to rise. In fact, according to hydraulics, when water is forced into a narrow tube with an opening at both ends, "it goes upwards against its natural inclination" (Kircher 1664-1665, p. 229). ${ }^{13}$ And - to Kircher - the enormous weight of the oceans, combined with the alternation of tides and the addition of storms, are more than plausible sources of pressure. This theory fully agrees with the famous passage from Ecclesiastes, and at the same time provides a congruent model of the hydrologic cycle, that is reasonably compatible with both the author's philosophic beliefs and the scientific knowledge of his time (see Figure 1).

The Italian Jesuit Mario Bettini, a skilled mathematician and astronomer, followed a different approach to explain the origin of springs. In his encyclopedic treatise, the Apiaria universae philosophiae mathematicae, he criticized Copernicanism, supporting the geocentric model. And his calculations, though starting from this wrong premise, led him to develop a rigorously coherent "system on the perpetual motion of rivers" (Bettini 1642, p. 24). ${ }^{14}$

In order to understand Bettini's theory, we need to focus on the fundamental principle of the Ptolemaic model, according to which the Earth is the center of the universe, and, therefore, also its center of gravity. However, since the distribution of land masses and oceans is extremely irregular, the center of gravity of the whole universe and the "center of mass" of the planet-so Bettini calls it - do not coincide; they are not "in the same point". ${ }^{15}$ Consequently, some zones of the planet, like the peaks of the mountains, are more distant from its center of mass than others, and are less subject to gravity. ${ }^{16}$ And as water is not fixed, it moves perpetually, in its eternal and vain attempt to restore equilibrium. ${ }^{17}$ Hence it goes from the oceans to the mountains "through hidden breaches in the Earth", ${ }^{18}$ rises, gives birth to springs and rivers, returns to the oceans, and so on. This "mathematical artifice of nature" (Bettini 1642, pp. 24-25) ${ }^{19}$ is a giant, perpetual motion, that - once more - conforms perfectly to the Holy Scriptures, and whose operation can be explained by means of ingenious mechanical models (see Figure 2: the Apiaria, just like the Mundus Subterraneus and the Anatomia physico-hydrostatica, is profusely illustrated with beautiful engravings). Bettini describes carefully these devices; but points out that they have just an illustrative purpose, since their size is too small for allowing perpetual motion to exist (Bettini 1642, pp. 15-16).

Many other works were performed by religious authors, in their efforts to provide theories of the origin of springs and of the water cycle that would allow heterogeneous knowledges, both scientific and philosophical, and a literal interpretation of the Bible to complement each other (Besson 1569; Majoli 1597; Lydiat 1605; Froidmont 1627, pp. 272-287; Du Hamel 1660, pp. 1239; Gassendi 1675, pp. 554-559; Lana Terzi 1686, pp. 184-186). Anyway, these were but a part of the many streams that contributed to solving the enigma. Other creeks joined the river. They

\footnotetext{
12 A striking - though debated-example of this conception is the Gaia hypothesis, proposed by James Lovelock and Lynn Margulis in the 1970s (Lovelock 1979).

Aqua pressa ubi exitum reperit, ultra naturalem inclinationem in altum ascendit.

Ratio aliqua motus perpetui fluviorum in orbe terrarum.

Centrum molis, et centrum gravitatis in terrae globo non sunt in eodem puncto, quia moles ex aquis, ac terris constans magis gravitat ex ea parte, ubi terrae sunt, circa quas minores marium sinus funduntur. 16 Dum igitur orbis terrarum centrum gravitatis collocatum continet in centrum universi, partes terreni globi, circa
quas maria ampliora affunduntur, sunt remotiore a centrum universi, ac proinde altiores, quam reliquae partes ambitus terrestris exiguis aquis affusi. Quite significantly, this phenomenon is also observed in the current heliocentric model. Not by chance, gravitational field strength measurements are a common geophysical tool today. Thanks to Isabel Fay Barton for the suggestion.

Affectat aequilibrium.

Per occultos terrae meatus.

Naturae mathematica machinatio.
} 
brought a different kind of water-in which theory, however important, had to give way to practice.

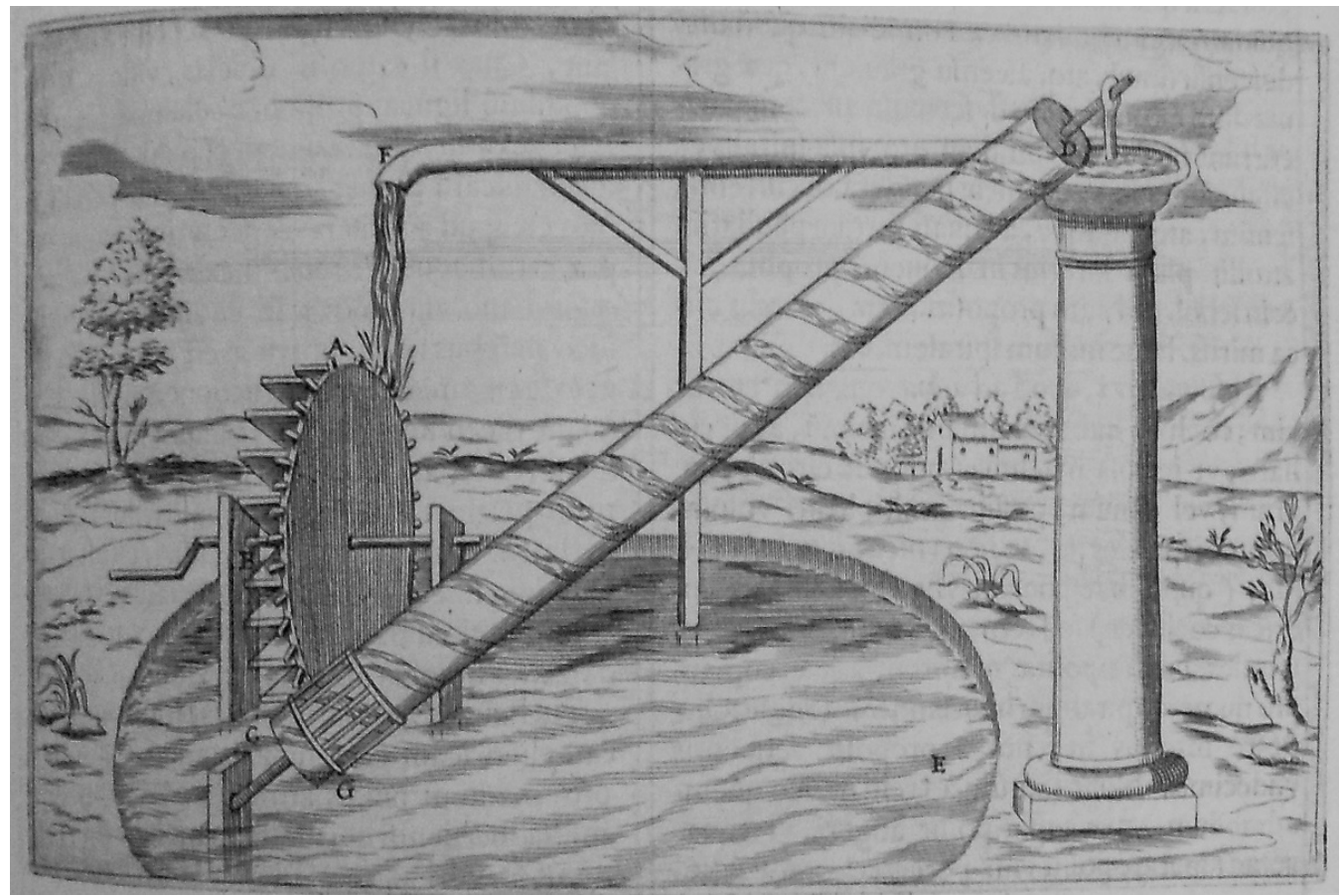

Figure 2. The perpetual motion of waters, according to Bettini's mechanical model (Bettini 1642, p. 15).

\section{NUMBERS, EXPLORATIONS, AND POTTERY}

Theorique: Do you think I am so ignorant as to believe more what you say than many philosophers who say that all waters come from the sea and return to it? Even old wives say the same thing, and we have always so believed. It is very presumptuous of you to want us to believe an entirely new doctrine, as if you were the ablest of philosophers.

Practique: I am quite certain I shall win out against you and all those who are of your opinion, even Aristotle and all the most excellent philosophers of all time: for I am quite sure that my opinion is correct. '. . .' If the springs of fountains came from the sea, how could they dry out in summer? Since the sea is no lower than in winter '...'. I give you as a general and certain rule that waters never rise higher than the springs whence they come. Don't you know that there are more fountains in the mountains than in the valleys: and even if the sea were as high as the highest mountain, still it would be impossible for mountain springs to come from the sea: the reason is, that to bring water from a high place to make it climb to another just as high, the pipe through which the water flows must necessarily be well enclosed, so that nothing leaks through it: otherwise the water, having come down into the valley, would never go up again to high places: but would come out at the first hole it would find (Palissy 1580, pp. 34-41). ${ }^{20}$

The English translation of all quoted passages comes from Palissy 1957.

Theorique: Me cuides tu si ignorant que je veuille adiouster plus de foy à ce que tu dis, qu'à un si gran nombre de philosophes, qui disent que toutes les eaux viennent de la mer et qu'elles y retournent? Il n'y à pas iusques aux vielles, qui ne tienne un tel langage; et de tout temps nous l'avons tous creu. C'est à toy une grande outrecuidance de nous vouloir faire croire une doctrine toute nouvelle, comme si tu estois le plus habil philosophe.

Practique: Je suis tout certain que ie le gaigneray contre toy et contre tous ceux qui sont de ton opinion, fut ce Aristote et tous les plus excellents philosophes qui furent iamais: car je suis tout asseuré que mon opinion est veritable. '. . ' Si ainsi estoit que les sources des fonteines vinssent de la mer, comment pouroyent elles tarir en 
Theorique and Practique are two quite obviously opposed characters, the one embodying the old philosophical doctrines, and the other being the voice of first-hand experience. And given the professional background of the author of this dialog, the French Huguenot potter, craftsman, and hydraulics expert Bernard Palissy (1510-1589), it is not difficult to guess who he rooted for. The year was 1580, and the treatise, entitled Discours admirables de la nature des eaux et fonteines, represented a declaration of war against any speculation not grounded on solid empirical work. Practique, the author's alter ego, refuses Theorique's arguments on the rise of sea water up the mountains and on its desalination by passage through rock and clay strata. As for the "theory of so many philosophers who say that fountains, streams or rivers are generated by a thick air, which comes out from under mountains, and say that this air begins to thicken, and some time later dissolves and becomes water", ${ }^{21}$ he is slightly inclined towards acceptance. But

'. . ' I deny that this is the sole cause of springs and fountains, far from it: for if you will consider that since the creation of the world, fountains, rivers, and brooks have been flowing continuously from these mountains, you will understand that it is impossible for these caverns to furnish enough water for a year, nay for a month, so many rivers flow daily (Palissy 1580, pp. 44-45). ${ }^{22}$

Palissy shares many traits with other 'artisan/practitioners' (Long 2011) whose mastery in various technical and artistic fields such as hydraulics, engineering, pottery, carpentry, weaving, painting, etc., deeply influenced the development of the new sciences during the early modern period. ${ }^{23}$ Still, this proud and unbending Huguenot represents a rather peculiar case in the context of the sixteenth century (and not so much for the content of his theory: already in 1569, another French Protestant author, Jacques Besson (1540-1573), refused the idea of secret passages connecting the oceans to the mountains (Besson 1569); ${ }^{24}$ and Agricola, in his De ortu et causis subterraneorum (Agricola 1546), took an even earlier stance against these subterranean waterways $^{25}$, consistent as he was with his hostility toward any philosophical speculation. The same inflexibility played very likely a major role in ratifying his grim end in the Bastille, where he was imprisoned for his religion at age 80 .

Religious quarrels aside, as a matter of fact, the next decades in Europe marked a boost in the experimental approaches to water. In 1628 Benedetto Castelli (1578-1643), a Benedictine monk and a faithful disciple of Galileo, published the Della misura dell'acque correnti (Castelli 1628) - a crucial work in the application of the scientific method to the study of rivers, as, "for the first time, the law of continuity was published and applied in a geometric form to define and to measure the discharge of a canal or a river in the case of steady flow" (Maffioli 1994, p. 37). ${ }^{26}$

esté? Veu que la mer n'est en rien moindre qu'en hyuer . . . '. Je te di pour une regle general et certaine, que les eaux ne montent iamais plus haut que les sources d'ou elles procedent. Ne sçais tu pas bien qu'il y à plus de fontaines és montaignes que non pas aux vallées: et quant ainsi seroit que la mer fust aussi haute que la plus haute montaigne, encores, seroit il impossible que les fonteines des montaignes vinssent de la mer: et la raison est, par ce que pour amener l'eau d'un lieu haut pour la faire monter en un autre lieu aussi haut, il faut necessairement que le canal par ou l'eau passe soit si bien clos qu'il ne puisse rien passer au travers: autrement l'eau estant dessendue en la valée elle ne remonteroit iamais és lieux hauts: mais sortiroit au prochain trou qu'elle trouveroit.

Theorique: Et que deviendra donc l'opinion de tant de philosophes qui disent, que les fonteines, fleuves ou rivieres, sont engendrees d'un aër espois, qui sort du dessouz des montaignes, de certainnes cavernes, qui sont dans les dittes montaignes, et disent qu'iceluy aër vient à s'espoissir, et quelque temps apres se dissoult et convertit en eau, qui cause la source des fontaines et rivieres?.

Practique: '. . 'je n'ye que ce soit la cause totale des sources des fonteines, tant s'ent faut: car si tu veux considerer que depuis la creation du monde, il est sorti continuellement des fonteines fleuves et ruisseaux desdites montagnes, tu connoistras bien qu'il est impossible que les dittes cavernes peussent fournir d'eau pour une annee non pas pour un mois, autant de fluves qui d'escoulent iournellement. On this topic, see Roberts et al. 2007, pp. XXV, 83-186; Maffioli 2010, pp. XII-XVIII, 11-14, 19-49, 51-63, 67, 101-103, 124-149, 259, 271-279, 322-329, 334-340; Long 2011.

See Maffioli 2010, pp. 102-110.

See Barton 2015.

For the most comprehensive studies on Benedetto Castelli and his works, see Maffioli 1994; Maffioli 2010. 
Another milestone in hydraulics was set a few years later, when Giovanni Battista Baliani (15821666), a Galilean correspondent and not entirely compliant collaborator, published the De motu naturali gravium solidorum et liquidorum (Baliani 1638). Baliani's interaction with Galileo led to the existence of a working limit for suction-pumps, which could not raise water above a maximum height of 18 Tuscan fathoms (slightly more than 10.5 meters). Moreover, as Galileo noted, this was a natural, not a technical limit. Inevitably, this notion brought into play the thorny issue of the existence of vacuum, and in the next years it would trigger endless diatribes - not only with Aristotelian and Cartesian authors, and with respect to the many different theories supposing the rise of sea water up the mountains through hidden channels, but also with not a few experimentalists (Maffioli 1994, pp. 105-109, 125, 168; Maffioli 2010, pp. 180-181, 334-335). The French hydrologist Pierre Perrault (1611-1680), for example, in his De l'origine des fontaines maintained the concept of horror vacui, for this was an essential element of his unconventional theory on the meteoric origin of springs. In fact, as he wrote, "there is a great difference between my thought and those who follow this usual idea" (Perrault 1674, p. 148). ${ }^{27}$

Perrault's model invoked the existence of a perpetual motion of water, according to which these rivers refilled both oceans and fountains. At the same time, he refused the Cartesian concept of subterranean heat (as presented in Descartes 1644, pp. 228-231) as a means to explain the rise of water, as it had no acceptable causal explanation. Hence the need for another process, for example the horror vacui, in obedience to which water could return, against gravity, from rivers to springs.

For they believe that waters from rain and melted snow fall on the Earth, soak into it until they encounter fatty earth or some other thing that stops them; upon which they flow toward some opening on the slope of a mountain; and I believe that rain does not soak into the Earth, nor does it go down to this fatty earth. They believe that the waters that fall on the high plains, are the cause of springs by means of this penetration which they assume; and I hold that all these waters are lost to the springs, and that they serve only to nourish plants and trees, and to make up puddles, ponds, and wells of short duration; and also to give off vapors that produce rain, snow and sleet. They believe that the rains that fall on the slopes of hills, are lost and of no use for springs, because thence they fall into rivers that carry them to the sea; and I believe on the contrary that they are the only ones that serve to produce and maintain springs because of this same fact that they fall into the rivers. They believe also that it is the springs which gather together to form rivers, and that if there were no springs there would be no rivers; and I myself believe that the rivers produce the springs, and if there were no rivers there would be no springs (Perrault 1674, pp. 148-150). ${ }^{28}$

This assumption distinguished Perrault from a great part of those scholars fully supporting the origin of fresh water from precipitation. Amongst them was the English polymath Robert Hooke (1635-1703) — who, as in many other fields of scientific enquiry to which he attended, proved to be one of the most brilliant and far-sighted minds of his time.

With respect to this topic, Hooke's most important writing can be found in an essay entitled Lectures de Potentia Restitutiva, or of Spring; the term "spring" referring to both the

27 Il y a une difference extrême entre ma pensée et celle de ceux qui suivent ce sentiment ordinaire. The English translation of all quoted passages comes from Perrault 1967.

28 Car ils croyent que les eaux des pluyes et des neiges fondües tombant sur la Terre, la penetrent jusques à ce qu'elles ayent rencontré de la terre grasse ou autre chose qui les arreste; surquoy elles coulent vers quelque ouverture sur le penchant d'une montagne; et moy je croy que la pluye ne penetre point la Terre, ni ne descend point jusques sur cette terre grasse. Ils croyent que les eaux qui tombent sur les plaines hautes, sont la cause des fontaines, par le moyen de cette penetration qu'ils supposent; et moy je tiens que toutes ces eaux-là sont perdues pour les fontaines, et qu'elles ne servent qu'à la nourriture des plantes et des arbres, et à faire des mares, des estangs et des puits de peu de durée; et aussi à donner des vapeurs qui produisent de la pluye, de la neige et de la gresle. Ils croyent que les pluyes qui tombent sur le penchant des collines, sont perdues et de nulle utilité pour les sources, par la raison que de là elles tombent dans les rivieres qui les emmenent à la mer; et moy je croy au contraire qu'il n'y a que celles-là qui servent à la production et entretien des sources par cette mesme raison qu'elles tombent dans les rivieres. Ils croyent aussi que ce sont les fontaines qui estant assemblées sont les rivieres, et que s'il n'y avoit point de fontaines il n'y auroit point de rivieres; et moy je croy que ce sont les rivieres qui sont les fontaines, et que s'il n'y avoit point de rivieres il n'y auroit point de fontaines. 
natural sources of water and the mechanical devices. As he acknowledges in this short treatise, "the original of springs is that which hath exercised the pens of many learned writers, and very various have been the conjectures concerning it" (Hooke 1678, p. 36). Nevertheless, his opinion is clear, and-he points out—it fully complies with the Holy Scriptures.

I conceive none more probable [theory] than that which seems to fetch its original from the History of the Creation mentioned in Holy Writ; that is, that there is a magazine of waters above as well as receptacle of waters upon or beneath the surface of the Earth; and that the air is that firmament which separates between the upper and lower waters, and between these two is the circulation of waters performed. The water being sometimes by a particular constitution of the air assisted by heat, rarified and separated into minuter parts, and so reduced into the form of air, and thereby being divided into particles really smaller than those of the air in compassing, and agitated with a greater degree of motion, they take up more space, and so become lighter than the ambient, and are thereby elevated and protruded upwards till they come to their place of poise or equilibrium in the air: at other times by a differing constitution of the air and deficiency of heat they lose their agitation, and many of them again coalesce, and so having less motion they condense and revert into water, and so, being heavier than the incompassing air, descend down again to the Earth in mists, rain, snow, hail, or the like (Hooke 1678, p. 36).

Significantly, Hooke finds no contradiction between this theory and the biblical account. The water cycle (because this is a water cycle, in the true sense of the word) is a clear truth, legitimated by both nature and religion. And

I think there is none doubts, but still it remains a difficulty (with those persons that grant this) that all rivers and springs should have their original from the water that falls or condences out of the air. To persuade such persons it may not possibly be unsuccessful to mention: first, that the great inundations or overflowing of rivers manifestly proceed either from the rain that immediately falls, or from the melting of snow or ice that hath formerly fallen on the more eminent parts of mountains '. . $\therefore$; secondly, that it hath been observed and computed that communibus annis et locis, there falls water enough from the sky in actual rain, snow, or hail upon the surface of England to supply all the water that runs back into the sea by the rivers, and also all that may be supposed to evaporate; nay, though the quantity of the first be supposed twice as much as really it is. This I have been assured by those that have both experimented and calculated it. Thirdly, that there is not yet certainly (that I know or have heard of) any other way of making salt water fresh, but by distillation; which, had there been such an art, it would in all probability have been made use of, and so there is little probability that the springs at the top of a high hill should proceed from the sea-water strained through the earth ‘. . . Fourthly, that this operation is constantly and most certainly performed by nature both in exhaling and drawing up fresh steams and vapours from the sea, and all moyst bodies, and in precipitating them down again in rain, snow, hail, but of the other we have no certainty (Hooke 1678, pp. 36-37).

However, "nullius in verba", says Hooke. "Let truth only prevail, and theories signifie no further than right reasoning from accurate observations and experiments doth confirm and agree with them" (Hooke 1678, pp. 39-40). And to tell the truth, in the second half of the seventeenth century, experiments and observations were still far from being unanimous about the origin of springs. Although a thorough discussion of Halley's methods is beyond the scope of this paper, his careful measurements on the hydrologic balance between evaporation, precipitation and runoff, persuaded him that rain and snow events did not suffice to replenish fresh water supplies. Thus he supposed that condensation phenomena, as dew or Cartesian 'alembics', gave an essential contribution to the water cycle. In Italy, the physician Bernardino Ramazzini, in his De fontium mutinensium admiranda scaturigine, supported a compound origin of fresh water, in which precipitation was complemented by both condensation of vapor into caverns and desalination of sea water by filtration through rock strata (Ramazzini 1691, pp. 56, 62). And the physician, chemist and mathematician Domenico Guglielmini (1655-1710), whose studies on fluid dynamics played a crucial role in the development of hydrology and hydrogeology, resorted 
to the opinion of "the most ingenious Descartes" as "perhaps the most probable, and the closest to the truth" (Guglielmini 1697, p. 41). ${ }^{29}$

Confused and inconclusive as this context may seem, the cumulative effect of the many studies performed in those decades led to a growing perception of the chemical and physical factors involved in the water cycle. And despite all the struggles and the exhausting philosophical debates, the circulation of experimental data and the spreading of theories among the European Republic of Letters distilled more and more the essence of the hydrogeological processes. In 1686, the French physicist and priest Edme Mariotte (1620-1684), a proud member of the Académie Royale des Sciences, published the Traité du mouvement des eaux et des autres corps fluides; ${ }^{30}$ and in the Second Discourse of this book, entitled De l'origine des fontaines, he supported without hesitation (and with plenty of measurements on the flow rate of the Seine) the meteoric origin of springs, without any concession to 'alembics' or rock filters.

The most remote heads of the Seine are near 60 leagues from Paris '..$\therefore$ If the Seine is cut by a perpendicular line, which passes five or six leagues from Paris, on the side of Corbeil, there are found springs towards the extremities of that line, which are distant from one another about 45 leagues. I suppose then that the contents of that whole extent of land is 60 leagues in length, and 50 in breadth, which makes 3,000 square leagues; the product of which being multiplied by $238,050,000$ amounts to 714,150,000,000; whence it appears, that the lands which furnish the waters of the Seine at Paris, receives from the rain $714,150,000,000$ cubic feet of water in a year.

The Seine above Pont-Royal '. . ', is then in its mean bulk, and its velocity at the surface is such, that it goes 150 foot in a minute, but it goes 250 when the waters are at their greatest height '. . '; let us say for a mean velocity 100 foot in a minute. The product of 400 foot, which is the breadth, multiplied by 5 the middle or mean depth, gives 2,000; for it is 8 or 10 foot deep in some places, in others 6,3 or 2; and the product of 2,000 by 100 foot makes 200,000 cubic feet, and consequently there passes through a section of the bed of the river Seine above Port-Royal, 200 thousand cubic feet in a minute; $12,000,000$ in a hour; $288,000,000$ in 24 hours; and 105,120,000,000 in a year; which is not the sixth part of the water that falls by rains and snow, which is $714,150,000,000$. It is plain then, that if the third part of the rain water was to be exhaled up in vapours immediately after it fell, and if half of the rest was to remain some upon the surface of the Earth to keep it wet '...', and some in the subterraneous places under great plains '. . ', there would still be enough [water] to produce those springs and rivers as they now appear (Mariotte 1686, pp. 31-33). ${ }^{31}$

And, answering those scholars who claimed that springs came from "the very top" of mountains, Mariotte remarked that he had

29 Ha l'ingegnosissimo Descartes apportata un'opinione forse la più probabile, e la più prossima al vero. On this topic, see Rappaport 1997, pp. 36, 39, 48, 197n; Maffioli 2010, pp. 260-319, 326, 330, 332; Luzzini 2013d, pp. $88,117 \mathrm{n}$.

30 See also Rappaport 1997, pp. 187-188; Luzzini 2013d, pp. 113-114, 151n.

31 The English translation of all quoted passages comes from Mariotte 1718.

Les sources les plus éloignées de la Seine sont à 60 lieuës de Paris à peu prés . . . . Que si l'on coupe la riviere de Seine par une ligne perpendiculaire qui passe à cinq ou six lieuës de Paris, du costé de Corbeil, on trouve des sources vers les extremitez de cette ligne qui sont distantes l'une de l'autre d'environ 45 lieuës. Je suppose donc que la continence de toute cette etenduë de païs est de 60 lieuës de longueur revestuë, et de 50 lieuës de largeur, qui font 3000 lieuës superficielles, dont le produit par 238.050.000 est 714.150.000.000, d'où l'on voit que les terres qui fournissent l'eau de la Seine à Paris, reçoivent des pluyes 714.150.000.000 pieds cubes d'eau en un an.

La Seine au dessus du Pont Rouge '. .' est alors dans sa moyenne grandeur, sa vitesse au haut de l'eau est telle qu'elle fait environ 150 pieds en un minute, elle en fait 250 quand les eaux sont en leur plus grande hauteur .... '; on peut prendre pour vitesse moyenne 100 pieds en une minute. Le produit de 400 pieds de largeur par 5 pieds de hauteur moyenne est 2000; car elle a 8 ou 10 pieds en des endroits et six, ou trois, ou deux en d'autres, et le produit de 2000 par 100 pieds, fait 200.000 pieds cubes, et par consequent il passe par une section du lit de la riviere de Seine au dessus du Pont Rouge 200 mille pieds cubes en une minutte, et 12.000.000 en une heure, et en 24 heures 288.000.000, et en un an 105.120.000.000, qui n'est pas la $6^{\circ}$ partie de l'eau qui tombe en un an par les pluyes et les neiges; sçavoir 714.150.000.000 pieds cubes. Il est donc manifeste que quand le tiers de l'eau des pluyes s'éleveroit en vapeurs incontinent aprés estre tombée, et que la moitié du reste demeureroit dans les terres superficielles pour les tenir moüillées '. . ', et dans les lieux soûterrains au dessous des grandes plaines '. . ', il y en auroit assez pour produire ces fontaines, et les rivieres telles qu'on les voit. 
'. . ' observed one of those springs in a mountain two leagues off of Dijon, which gives a great quantity of water; and when you come very near it, you can't see above 40 feet in height of ground above it where the declivity is very steep; but if you look at this upper mountain from a far off, you see it extend itself with a gentle shelving for above 500 fathom in length, and 200 in breadth. Now, in that space there falls rain enough to feed that spring (Mariotte 1686, pp. 26-27). ${ }^{32}$

Within a handful of years, other voices joined in. The Danish physician Caspar Bartholin (the Younger, 1655-1738), in 1689 published a treatise whose title was more eloquent than any further description: De fontium fluviorumque origine ex pluviis dissertatio physica (Physical Dissertation on the Origin of Springs and Rivers from Rains). Not by chance, Bartholin refuted both rock filtration and distillation as natural means to produce fresh water. And just like Mariotte, he pointed out that no springs existed on the very top of mountains. This phenomenon was simply impossible, as it would have "contradicted the own laws of hydrostatics and equilibrium", and, therefore, it would have been "against nature itself" (Bartholin 1689, p. 34). ${ }^{33}$ The same arguments were used a couple of decades later by Edward Barlow (1639-1719), an English Catholic priest and mechanics expert who is better known for having invented the rack and snail striking mechanism for striking clocks, a fundamental innovation in clock making. But Barlow was skilled in more fields than just technology; in his Meteorological Essays Concerning the Origin of Springs, he described how his explorations in the mountains and in caves convinced him that all the springs, whether they were on the surface ("day-springs"), aquifers ("topsprings"), or even deeper in the Earth ("bottom-springs" and "deep-springs"), were nourished by rain water alone. Any other cause was not only impossible, but contrary to the very laws of nature.

So plain doth it appear from all that has been alledged both pro and con, that rain abundantly furnisheth all the fountains in the world with water; without being beholden to such imaginary apprehensions, as that air condensed into water by the coldness of the Earth; or vapours, raised by its heat out of its bowels; much less streams conveyed thro' its cavities out of the ocean, can in the least affect them; but rather, rain alone performs the work: which never falls, but gives them an increase in the same measure; nor is withdrawn, but they suffer a proportionable diminution: so vainly do we grope at Noon-Day for abstruse and occult causes, while the only true is plain and manifest before our eyes (Barlow 1715, pp. 37-38).

In the same year that Barlow's book was printed, another treatise dealt a lethal blow to both 'alembics' and rock filters. Antonio Vallisneri (1661-1730), physician, naturalist and Professor of Medicine at the University of Padua, published his Lezione accademica intorno all'origine delle fontane (Academic Lecture on the Origin of Springs, Vallisneri 1715). The centerpiece of Vallisneri's thesis was a mass of experimental data that he collected during a journey across the Northern Apennines. Already in 1705, he had written a report in Latin of this adventure, the Primi itineris per Montes specimen Physico-Medicum (Physical-Medical Example of a First Journey through the Mountains). ${ }^{34}$ He had sent a copy of it to the Royal Society, hoping eagerly for publication in the Philosophical Transactions. This honor was not granted to the piece, which remained unpublished. Two decades later a synthesis in Italian was published in two parts, or Extracts-Estratto d'alcune Notizie intorno alla Provincia della Garfagnana and

32 On voit quelques-fois des fontaines bien élevées dans le haut des montagnes, et quelques-uns soûtiennent qu'elles sont au plus haut lieu; j'ay remarqué une de ces fontaines dans une montagne à deux lieuës de Dijon, elle donne beaucoup d'eau: et quand on en est fort prés on ne voit qu'environ quarante pieds de hauteur de terrain au dessus dont la pente est tresroide; mais si l'on regarde de loin cette montagne, on la voit s'étendre par une pente assez sensible, jusques à plus de cinq cens toises de longueur et deux cens de largeur. Or en cet espace il tombe assez d'eau des pluyes pour entretenir cette fontaine comme il sera prouvé ensuite.

33 Patet vel ex ipsis legibus hydrostaticis et aequilibrio, quod in aquis servat natura, adeo ut hoc prorsus ipsi repugnaret naturae, si de fontibus loquamur in elevatiori loco repertis.

34 Antonio Vallisneri, Primi itineris per Montes specimen Physico-Medicum. Archivio di Stato di Reggio Emilia, Archivio Vallisneri, 10, Scritti, minute e appunti scientifici e letterari d'Antonio Vallisneri sr., mazzo IV. 
Continuazione dell'Estratto (Vallisneri 1722; Vallisneri 1726) - in the Supplementi al Giornale de' Letterati d'Italia. As to the original manuscript, it was considered lost until 2009, when Dario Generali and the author were lucky enough to find it in the State Archives of Reggio Emilia. This text, along with the two Estratti, provided such a huge amount of information that it was possible to study the itinerary in great detail, including an experimental replication of Vallisneri's journey and observations (Luzzini 2008; Luzzini 2010; Luzzini 2011b; Luzzini 2011c; Luzzini 2013d, pp. 90-107)..$^{35}$

Vallisneri travelled a total distance of about 130 kilometres. From the hills south to Reggio Emilia, he went through the San Pellegrino Pass, reaching at last Tuscany and the Apuan Alps, in the western end of Garfagnana (see Figure 3). San Pellegrino, being one of the highest elevations

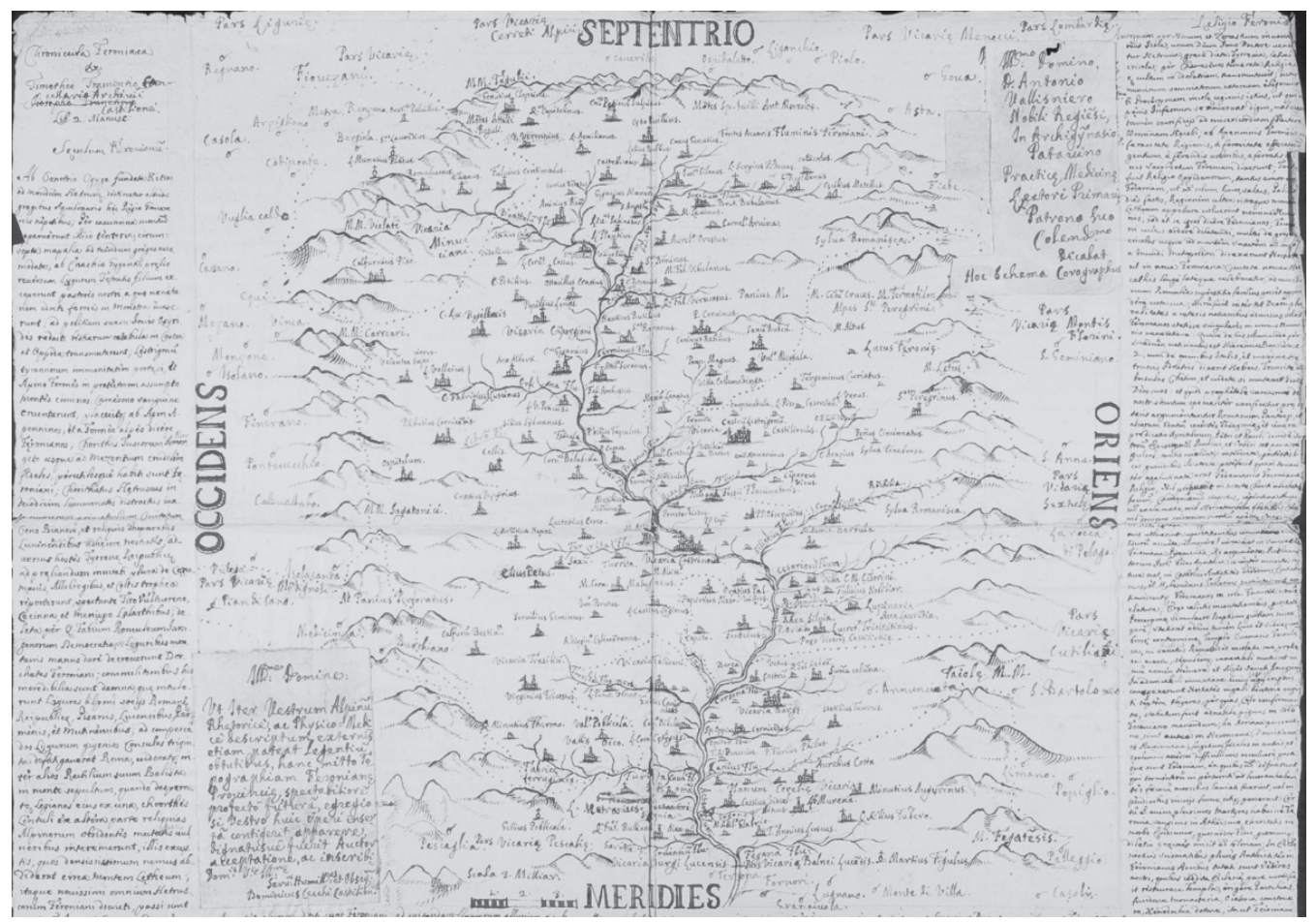

Figure 3. A map from Vallisneri's manuscript, the Primi itineris specimen, depicting the Tuscan region of Garfagnana (State Archive of Reggio Emilia, Archivio Vallisneri, 10, Scritti, minute e appunti scientifici e letterari d'Antonio

Vallisneri sr., mazzo IV).

in the Northern Apennines, afforded a privileged viewpoint for the author, who studied both the pass and the alpine tundra above. By "wandering, and observing all those rough, and rugged deserts", ${ }^{36}$ he paid special attention to the snows that-even during summer-covered them. According to some shepherds, these snows existed "eternally in certain dark, gelid, deep places, melting little by little" (Vallisneri 1722, p. 287): $:^{37}$

The snows, which were barely melted, came down from those slopes, and some continued their way by originating foaming, and roaring streams that fell down, others hid, and went to ground into pits,

35 I am currently working towards a critical edition of Vallisneri's manuscript, which will be published within the Edition Open Sources Project (http://www.edition-open-sources.org/) by the end of 2016. The book will be available in Open Access, and will feature a facsimile of the source, a scholarly introduction, a transcription and an English translation of the Latin text, philological, scientific, and historical notes, and an interactive map of Vallisneri's journey.

$36 \quad$ Vagando, e osservando tutti que' crudi, ed aspri circonvicini deserti.

37 In certi oscuri, freddissimi fondi, eterne dimorano, dileguandosi a poco a poco. 
and caverns, vanishing. It was in that moment that our author discovered the origin of springs ' . .', having clearly known how far from truth are those philosophers which assume it is from the sea, or from their dreamed alembics in the bowels of the mountains (Vallisneri 1722, p. 289). ${ }^{38}$

A few days later, Domenico de' Corradi d'Austria (1677-1756), miner and chief superintendent of artillery on behalf of the Duke of Modena and Reggio, assisted Vallisneri in the exploration of the iron mines in Garfagnana and of a mysterious cavern, the Tana che urla ("Antro ululante", or "Screaming Cave"). Thanks to these new experiences, Vallisneri was able to provide other evidence in support of his theory on the meteoric origin of springs, further weakening rival systems. ${ }^{39}$ Besides, this second aim to dispute competing theories was achieved not just by field research, but also by what could now be defined as a laboratory test. And in this specific case, a crucial role was played by a humble apothecary from Leghorn, Diacinto Cestoni (1637-1718).

This peculiar character seemed to embody the claim of the superiority of practice over speculation. Despite his lack of academic training, his intellectual curiosity and his vast scientific experience earned him a first-rate competence in the natural sciences (Generali 2004; Generali 2007, pp. 319-350; Tanga 2007; Generali 2010). And indeed Cestoni was essential in shaping Vallisneri's research. From 1697 to 1718 the two friends exchanged letters almost once a week. Eighteen years before the publishing of the Lezione Accademica, in a letter to Vallisneri dated December 2, 1697, he firmly stated that

'. . ' it is clear that the salt water of all universe cannot be made fresh and drinkable by filtration, whatever its proportion. My profession is an unerring teacher in this regard, and I know for sure that salt water has to be distilled in order to be converted into fresh water: and in all universe this job is perpetually carried out by the heat from the sun and from the air, and through the rains it [the water] comes down again: therefore, the rains are surely the nourishment for the springs and rivers of this world (Cestoni 1940, p. 84). ${ }^{40}$

Most likely, these words were gold to Vallisneri. Still, he wished to verify personally the truth, by performing an unusual experiment. As he wrote in 1698,

It occurred to me to do this experience, in order to see if the springs of the mountains, of the valleys, and of other places come from the sea or from rain water; in fact, they say that once thrown a well sealed pot into the sea, the water that soaks in through the pores of the pot becomes fresh, leaving the salt outside. Thus, I ordered to make a ball with pottery clay, and having put it into water, the water

Colavano allora (dice) le nevi, che con istento squagliavansi, giù per lo dosso di que' ciglioni, e formando spumanti, e strepitosi rivi al basso piombavano, seguendo oltre il loro corso, altre nascondendosi, e rimpiattandosi dentro buche, e caverne, né più veggendosi. Allora fu, che il nostro autore scoperse l'origine delle fontane '. . ', avendo chiaramente conosciuto quanto male al vero s'accostino que' filosofi, che le riconoscono dal mare, o da' sognati lambicchi dentro le viscere de' monti. It is worth noting that Vallisneri's exploration was performed in the summer of 1704: that is, in the middle of the Little Ice Age, a period of cooling which occurred in the Northern Hemisphere from the sixteenth to the nineteenth centuries. Nowadays, it is almost impossible to find snow on the Northern Apennines during summer.

39 In fact, in the XVIII century, the (however prevailing) meteoric theory was still debated. In 1725 , for example, Niccolò Gualtieri's Riflessioni sopra l'origine delle fontane (Considerations on the Origin of Springs) strongly opposed Vallisneri's system. Moreover, several other, important authors as Bernardino Ramazzini, Edmond Halley, Luigi Ferdinando Marsili, and Domenico Guglielmini, still supported the theory of a compound origin of freshwater, defending their previous works on this topic (Halley 1687; Halley 1691; Ramazzini 1691; Guglielmini 1697; Marsili 1725; Marsili 1930). See Luzzini 2013b; Luzzini 2013d, pp. 69-159.

. . .' chiara cosa è, che l'acqua salata di tutto l'universo non è possibile ridurla dolce, e bevibile per via di filtrazione, intendo di qual si sia porzione. La mia professione è maestra infallibile di tal dottrina, e so di certo, che a voler ridurre dolce l'acqua salata, è necessario distillarla: e questo lavoro del distillare lo fa incessantemente il calor solare, et aereo in tutto l'universo, e poi per via di pioggie torna a venir di nuovo a basso: sicché asseverantemente le pioggie sono l'alimento delle fontane, e fiumi di questo mondo. On this specific topic, see Generali 2007, pp. 328-330; Tanga 2007, pp. 143-145; Luzzini 2011c, pp. 350-354; Luzzini 2013a; Luzzini 2013d, pp. 109-110. 
took eight days to penetrate, since I ordered to fire it in the kiln for a long time. Having broken the ball, I found that the salt water soaked in with no loss of salt. ${ }^{41}$

Immediately he wrote to "Mr Cestoni in Leghorn", who, in the meanwhile, had independently performed a similar test. He "prepared a vase '. . .' made of a sort of white, unglazed clay", 42 shutting it with sealing wax (see Figure 4). Then he tied it to a stone, and threw it into the sea (Cestoni 1940, pp. 109-110). He opened it ten days later, and found salt water inside (Cestoni 1940, pp. 111-112). Therefore, these two autonomous experiments showed that "the sea water becomes fresh only by distillation, and not by filtration". ${ }^{3}$

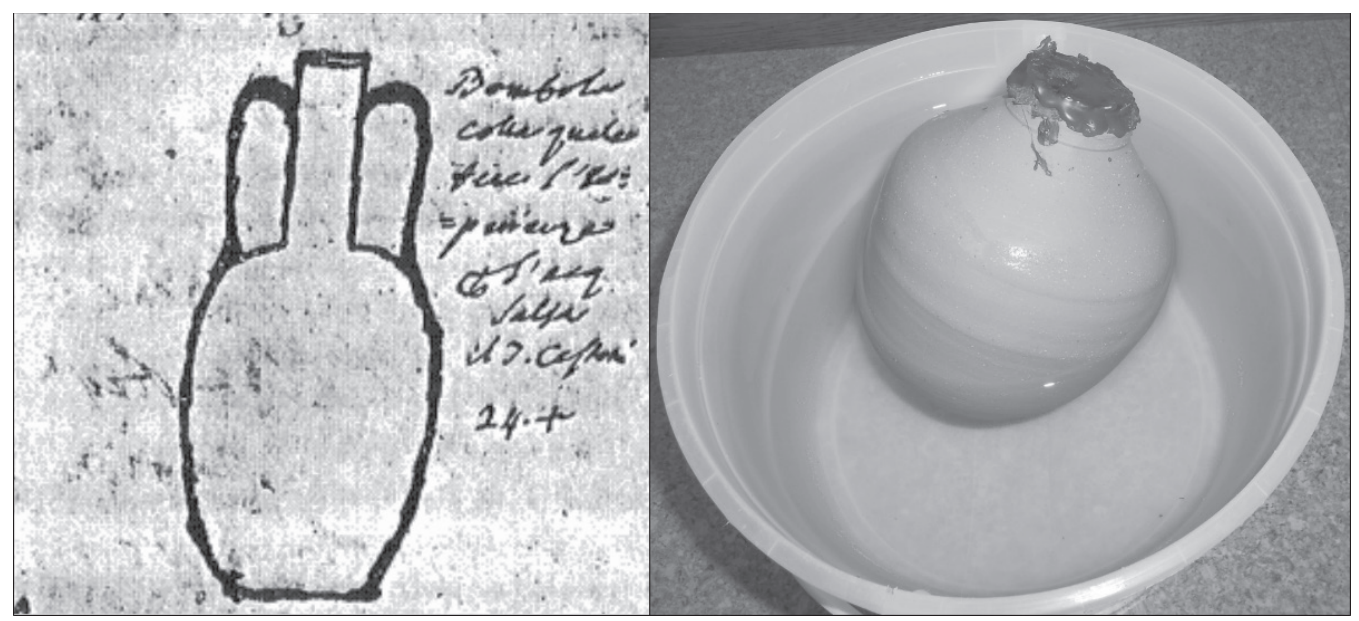

Figure 4. On the left, Cestoni's sketch of his vase, or "bombola", in a letter to Vallisneri in 1698 (Tanga 2007, p. 143). On the right, a replication of Cestoni's and Vallisneri's experiment, as it was performed in July 2014 at the Linda Hall Library in Kansas City, MO (http://vimeo.com/102054014). A special thanks goes to Nancy Green, whose mastery of pottery techniques made the experiment possible.

\section{UNIFORMITY (AND COMMON SENSE, AGAIN)}

From a modern point of view, the 'pottery test' may seem equivocal, obvious, or worthless. ${ }^{44}$ Ironically, and significantly, these very doubts can be considered as a powerful means to explain and support science's need for a history of science.

As many historians working in multidisciplinary contexts may attest, an astounding number of 'hard' scientists, still today, uncritically take for granted the uniformity of natural laws across time and space. But in the philosophical and scientific framework of the seventeenth and eighteenth centuries, such an idea was still far from being accepted unanimously both by the Republic of Letters and by the heterogeneous multitude of the so-called common people. This notion of uniformitarianism, which was a legacy of Galileo's theories (and which in the next

Mi saltò in capo di fare questa esperienza per vedere, se le fontane de' monti, delle valli, ed altri luoghi vengano dal mare, o se dall'acque piovane, perché dicono, che gittata una pentola ben chiusa in mare l'acqua, che dentro penetra per i pori della pentola resta dolce, lasciando al di fuori la salsedine. Feci dunque fare una palla vuota di terra da pignatte, e messa nell'acqua, tardò otto giorni a trapellar l'acqua, perché l'aveo fatta ben cuocere nella fornace. Rotta la palla trovai l'acqua salsa penetrata senza perdere il sale (Antonio Vallisneri, Quaderni di osservazioni. Biblioteca Estense di Modena, Raccolta Campori, 701-707, $\gamma$. D. 6, 36-42, Quaderno V, c. 42r).

4 Una bombola '...' di terra bianca non invetriata.

L'acqua del mare dolcifica solo per destillazione, e non per filtrazione (Antonio Vallisneri, Quaderni di osservazioni. Biblioteca Estense di Modena, Raccolta Campori, 701-707, $\gamma$. D. 6, 36-42, Quaderno V, c. 42v). It is worth noting that the geological process of membrane filtration actually allows the filtering of brines percolating through thick shale beds. We can't help acknowledging that this phenomenon, although involving different materials, periods, and means (it occurs through chemical reactions and adsorption, and not through physical filtration, as many early modern authors supposed), seems to contradict Cestoni's and Vallisneri's experiment. On this topic, see Hanor 1994 (thanks to Isabel Fay Barton for the valuable information). 
centuries would be refined and improved by the work of countless scholars), ${ }^{45}$ implied an epistemological revolution, affecting both scientific concepts of experimental verification and experimental observation. And not surprisingly, such issues as the origin of springs or the hydrologic cycle were no exception, as is proven by the emblematic case of Niccolò Gualtieri (1688-1744).

In 1725, this ambitious physician and naturalist from Florence published a treatise entitled Riflessioni sopra l'origine delle fontane (Considerations on the Origin of Springs), launching a fierce and ironic attack against Vallisneri's theory, and, more broadly, against the exclusive meteoric origin of fresh water. And one of the main arguments he used relied precisely on the spatial and temporal validity of the observations reported in the Lezione Accademica. How could Vallisneri be so sure that what he had observed in the Apennines also happened in the "more distant provinces" of the world, that he could not see "from the windows of Modena"? What about the immense African continent, or the even more distant Americas, for example (Gualtieri 1725 , p. 155-156), where springs and rivers may have had different origins? ${ }^{46}$

Gualtieri's doubts were not groundless speculations, in a time when the mere concept of 'field research' was still far from being unanimously defined. Despite the fact that uniformitarianism is considered today to be an essential element of science, it struggled to assert itself, raising ferocious opposition and debate at least until the first half of the nineteenth century. Yet, this tangled, tormented path was not a peculiarity of uniformitarianism. Our collective understanding of such words as 'nature', 'truth', and 'science', is a consequence of the development of many turbulent and intricate backgrounds. It is also due to the contributions of those who searched and suggested new ways, though seemingly unsuccessful in light of history, that the - still uncertain - path of science towards an understanding of nature could evolve. For scientific progress is much more the outcome of a humble, fragile, patient, and collective enterprise, than the result of the work of a few brilliant, heroic geniuses.

\section{ACKNOWLEDGEMENTS}

I wish to express my heartfelt thanks to the Linda Hall Library of Science, Engineering and Technology in Kansas City, MO (USA), and to the entire staff of the History of Science Center, for allowing me to conduct this research. A special gratitude goes to Bruce Bradley, Nancy Green, Donna Swischer, Eric Wade, Nancy Officer, Cindy Rogers, Bill Ashworth, and Scott Reiter, who supported and fostered my work with their invaluable help. Thanks also go to Isabel Fay Barton and Gian Battista Vai for reviews of an earlier version of this paper.

\section{ARCHIVES}

Da Vinci, Leonardo. Codex Atlanticus. Veneranda Biblioteca Ambrosiana, Milan, ff. 433, 468.

Vallisneri, Antonio. Quaderni di osservazioni. Biblioteca Estense di Modena, Raccolta Campori, 701-707, Gamma. D. 6, 36-42, Quaderno V.

Vallisneri, Antonio. Primi itineris per Montes specimen Physico-Medicum. Archivio di Stato di Reggio Emilia, Archivio Vallisneri, 10, Scritti, minute e appunti scientifici e letterari d'Antonio Vallisneri sr., mazzo IV.

45 On uniformitarianism, see Gould 1965; Rudwick 1972, pp. 110, 130-132, 169-172, 179, 185-188, 231, 235, 259; Albritton 1980, pp. 87-88, 100, 132, 139-147, 186-189, 215; Faul and Faul 1983, pp. 89, 90-91, 138, 184, 218; Young 1995, pp. 176, 178, 182, 209, 246, 248, 260, 262-263, 270, 285, 290, 292-293, 296; Oldroyd 1996, pp. 82, 134, 136-139, 142, 143, 177, 202, 301, 330, 331; Rappaport 1997, pp. 95, 162, 164, 167, 205-206, 238-242, 246.

$46 \quad$. . . e pure trattandosi d'un sistema, che universalmente convenir deve a tutto il mondo, non sarà fuor di proposito il dar così alla sfuggita un'occhiata anche alle province più lontane, ed alle montagne dell'Affrica, le quali, perciocché non si vedono dalle finestre, come quelle di Modena '. . ' pare, che co' loro fonti, e fiumi più malagevolmente s'accordino colla di lei sentenza '. . .'. See also Gualtieri 1725, pp. 157-174. On this topic, see Luzzini 2013d, pp. 143-147. 


\section{REFERENCES}

Agricola, Georgius (Bauer, Georg). 1546. De ortu et causis subterraneorum libri V. Basileae: Per Hieronimymum Frobenium et Nic. Episcopum.

Albritton, Claude C. Jr. 1980. The Abyss of Time. Changing Conceptions of the Earth's Antiquity after the Sixteenth Century. San Francisco: Freeman Cooper.

Aristotle. ca. 340 BC. Meteorology.

Baldini, Massimo. 1981. Vallisneri e la scoperta dell'origine delle fontane perenni. Brescia: La Scuola.

Baldini, Ugo. 1980. L'attività scientifica nel primo Settecento. In: Storia d'Italia, Annali, 3, Scienza e tecnica nella cultura e nella società dal Rinascimento a oggi, edited by Gianni Micheli, 465-529. Turin: Einaudi.

Baliani, Giovanni Battista. 1638. De motu naturali gravium solidorum et liquidorum. Genuae: Ex Typograhia Io. Mariae Farroni, Nicolai Pesagnii, et Petri Francisci Barberii, soc.

Barlow, Edward. 1715. Meteorological Essays, Concerning the Origin of Springs, Generation of Rain, and Production of Wind. London: Printed for John Hooke, at the Flour-de-luce; and Thomas Caldecott, at the Sun, both against St. Dunstan's Church in Fleet-street.

Bartholin, Caspar. 1689. De fontium fluviorumque origine ex pluviis dissertatio physica. Hafniae: Literis Regiae Maiest. et Universit. Typographi Johannis Philippi Bockenhoffer.

Barton, Isabel F. 2015. Georgius Agricola's contributions to hydrology. Journal of Hydrology 523: 839-849.

Battistini, Andrea. 2000. Galileo e i Gesuiti. Miti letterari e retorica della scienza. Milan: Vita e Pensiero.

Becher, Johann Joachim. 1669. Physicae subterraneae libri duo. Francofurti: Imp. Joh. Davidis Zunneri.

Besson, Jacques. 1569. L'art et science de trouvers les eaux et fontaines cachees soubs terre, autrement que par les moyens vulgaires des agriculteurs et architectes. Orleans: Pour P. Trepperel.

Bettini, Amalia. 1997. Cosmo e Apocalisse. Teorie del Millennio e storia della Terra nell'Inghilterra del Seicento. Florence: Olschki.

Bettini, Mario. 1642. Apiaria universae philosophiae mathematicae. Tomus I. Bononiae: Typis Io. Baptistae Ferronij.

Borgato, Maria Teresa (ed.). 2002. Giambattista Riccioli e il merito scientifico dei Gesuiti nell'età barocca. Florence: Olschki.

Cardano, Girolamo. 1550. De subtilitate libri 21. Norimbergae: Apud Ioh. Petreium.

Cardano, Girolamo. 1557. De rerum varietate Libri XVII. Basileae: Henrichum Petri.

Castelli, Benedetto. 1628. Della misura dell'acque correnti. Roma: Nella Stamparia Camerale.

Cestoni, Diacinto. 1940. Epistolario ad Antonio Vallisneri, edited by Silvestro Baglioni. Part I. Rome, Reale Accademia d'Italia.

Cohn, Norman. 1996. Noah's Flood. The Genesis Story in Western Thought. New Haven and London: Yale University.

Dal Prete, Ivano. 2007. Scienza e Società nel Settecento veneto. Il caso veronese 1680-1796. Milan: Franco Angeli.

Dean, Dennis R. 1981. The age of the Earth controversy: beginnings to Hutton. Annals of Science 38: 435456.

Dean, Dennis R. 1985. The rise and fall of the Deluge. Journal of Geological Education 33: 84-93.

Descartes, René. 1644. Principia Philosophiae. Amstelodami: Apud Ludovicum Elzevirium.

Dooge, James C. I. 1974. The development of hydrological concepts in Britain and Ireland between 1674 and 1874. Hydrological Sciences Bulletin 19: 279-302.

Dooge, James C. I. 2001. Concepts of the hydrological cycle. Ancient and modern. In: OH2, Origin and History of Hydrology. Electronic edition on cd. Dijon: Université de Bourgogne.

Du Hamel, Jean Baptiste. 1660. De meteoris et fossilibus libri duo. Liber Primus. Parisiis: Apud Petrum Lamy, in magna aula Palatii, secunda columna, sub Magno Caesare.

Fabre, Pierre-Jean. 1639. Hydrographum spagyricum. Tolosae Tectosagum: Apud Petrum Bosc.

Fabri, Honoré. 1665. Dialogi physici, in quibus de motu terrae disputatur, marini aestus nova causa proponitur, necnon aquarum \& mercurij supra libellam elevatio examinatur. Lugduni: Sumptibus Christophori Fourmy, in vico Mercatorio, sub signo Occasionis.

Faul, Henry and Faul, Carol. 1983. It Began with a Stone. A History of Geology from Stone Age to the Age of Plate Tectonics. New York: John Wiley \& Sons.

Feingold, Mordechai (ed.). 2003. Jesuit Science and the Republic of Letters. Cambridge, MA and London: The MIT Press.

Fludd, Robert. 1617. Utriusque Cosmi Maioris scilicet et minoris metaphisica, phisica atque technica Historia. Oppenhemii: Aere Johan-Theodori de Bry, Typis Hieronymi Galleri.

Froidmont, Libert. 1627. Meteorologicorum libri sex. Antuerpiae: Ex Officina Balthasaris Moreti. 
Gassendi, Pierre. 1675. Animadversiones in Decimum Librum Diogenis Laertii, qui est De vita, moribus, placitisque Epicuri. Lugduni: Sumptibus Francisci Barbier, Typographi Reg.

Generali, Dario. 1996. La biblioteca gesuitica del Collegio Braidense di Milano. In: Per una storia critica della scienza, edited by Marco Beretta, Felice Mondella, and Maria Teresa Monti, 331-346. Milan: Cisalpino.

Generali, Dario. 2004. Uno speziale che "superava la sua condizione". Il caso dell'invisibilità postuma di Diacinto Cestoni. In: Figure dell'invisibilità. Le scienze della vita nell'Italia d'Antico Regime, edited by Maria Teresa Monti and Marc J. Ratcliff, 83-118. Florence: Olschki.

Generali, Dario. 2007. Antonio Vallisneri. Gli anni della formazione e le prime ricerche. Florence: Olschki.

Generali, Dario. 2010. Diacinto Cestoni. Uno speziale sei-settecentesco tra invisibilità e riscoperta storiografica. Vita pensata $3: 35-37$.

Gould, Stephen J. 1965. Is uniformitarianism necessary? American Journal of Science 263 (3): 223-228.

Gould, Stephen J. 1987. Time's Arrow, Time's Cycle. Myth and Metaphor in the Discovery of Geological Time. Cambridge, MA and London: Harvard University.

Gould, Stephen J. 2004. Father Athanasius on the isthmus of a middle state. Understanding Kircher's paleontology. In: Athanasius Kircher: The Last Man Who Knew Everything, edited by Paula Findlen, 207-237. New York and London: Routledge.

Gualtieri, Niccolò. 1725. Riflessioni sopra l'Origine delle Fontane, descritte in forma di Lettera dal Dottore Niccolò Gualtieri all'Altezza Reale di Violante Beatrice di Baviera Gran Principessa di Toscana Governatrice di Siena. Lucca: Per Leonardo Venturini.

Guglielmini, Domenico. 1697. Della natura de' fiumi Trattato fisico-matematico. Bologna: Per gl'Eredi d'Antonio Pisarri.

Guntau, Martin. 1989. Concepts of natural law and time in the history of geology. Earth Sciences History 8: $106-110$.

Halley, Edmond. 1687. An estimate of the quantity of vapour raised out of the sea by the warmth of the sun. Philosophical Transactions XVI: 366-370.

Halley, Edmond. 1691. On the circulation of the vapours of the sea and the origin of springs. Philosophical Transactions XVII: 468-473.

Hanor, Jeffrey S. 1994. Origin of saline fluids in sedimentary basins. In: Geofluids: Origin, Migration and Evolution of Fluids in Sedimentary Basins, edited by John Parnell, 151-174. London: The Geological Society.

Harrison, Peter. 1998. The Bible, Protestantism, and the Rise of Natural Science. Cambridge: Cambridge University Press.

Herbinius, Johannes. 1678. Dissertationes de admirandis mundi cataractis. Amstelodami: Apud JanssonioWaesbergios.

Hooke, Robert. 1678. Lectures de Potentia Restitutiva, or of Spring, Explaining the Power of Springing Bodies. London: Printed for John Martyn Printer to the Royal Society, at the Bell in St. Paul's Church-Yard.

Kircher, Athanasius. 1660. Iter extaticum coeleste. Herbipoli: Sumptibus Joh. Andr. \& Wolffg. Jun. Endterorum haeredibus, Prostat Norimbergae apud eosdem.

Kircher, Athanasius. 1664-1665. Mundus subterraneus. Amsterodami: Apud I. Sansonium et E. Weyerstraten.

Kölbl-Ebert, Martina (ed.). 2009. Geology and Religion: A History of Harmony and Hostility. London: The Geological Society.

Lana Terzi, Francesco. 1686. Magisterium naturae, et artis. Tomus II. Brixiae: Per Io. Mariam Ricciardum.

Long, Pamela O. 2011. Artisans/Practitioners and the Rise of the New Sciences, 1400-1600. Corvallis, OR: Oregon State University Press.

Lovelock, James E. 1979. Gaia: A New Look at Life on Earth. Oxford: Oxford University Press.

Luzzini, Francesco. 2008. La Tana che urla: cenni di speleologia vallisneriana. In: Antonio Vallisneri. La figura, il contesto, le immagini storiografiche, edited by Dario Generali, 349-369. Florence: Olschki.

Luzzini, Francesco. 2010. Cavità naturali ed artificiali in Garfagnana e Lunigiana. Le esplorazioni di Antonio Vallisneri. In: Antonio Vallisneri dalla Garfagnana alla Scienza, edited by Pietro Rocchi, 93-124. Lucca: Maria Pacini Fazzi Editore.

Luzzini, Francesco. 2011a. Le Scienze della Terra nella corrispondenza milanese di Antonio Vallisneri: Clelia e gli altri. In: Clelia Grillo Borromeo Arese. Un salotto letterario settecentesco tra arte, scienza e politica, edited by Dario Generali, Vol. 1, 113-125. Florence: Olschki.

Luzzini, Francesco. 2011b. Nel gran libro della natura. Antonio Vallisneri e le scienze della Terra: il viaggio montano del 1704. Catalogue of the exhibition. Reggio Emilia: Centro Studi Lazzaro Spallanzani. 


\section{EARLY MODERN SCIENCE AND THE ORIGIN OF SPRINGS}

Luzzini, Francesco. 2011c. Multa curiosa. Vallisneri’s early studies on Earth sciences. Nuncius 26 (2): 334 354.

Luzzini, Francesco. 2012a. "Tutto pien di natura tacito". Le scienze della Terra nel "Giornale de' Letterati". In: Il "Giornale de' letterati d'Italia" trecento anni dopo. Scienza, storia, arte, identità (1710-2010), edited by Enza del Tedesco, 49-60. Pisa and Rome: Fabrizio Serra Editore.

Luzzini, Francesco. 2012b. Contro i lambicchi. Antonio Vallisneri e l'origine delle sorgenti. Acque Sotterranee, Italian Journal of Groundwater 1: 81-82.

Luzzini, Francesco. 2013a. Il Signor Cestoni alla prova delle pignatte. Acque Sotterranee, Italian Journal of Groundwater 1: 95-96.

Luzzini, Francesco. 2013b. La sofferta chiusura del cerchio. Il contributo di Edmond Halley all'idrologia. Acque Sotterranee, Italian Journal of Groundwater 2: 63-64.

Luzzini, Francesco. 2013c. Il paradosso di Kircher (che paradosso non è). Acque Sotterranee, Italian Journal of Groundwater 3: 65-66.

Luzzini, Francesco. 2013d. Il miracolo inutile. Antonio Vallisneri e le scienze della Terra in Europa tra XVII e XVIII secolo. Florence: Olschki.

Luzzini, Francesco. 2014. L'autarchia delle acque. Mario Bettini e il moto perpetuo. Acque Sotterranee, Italian Journal of Groundwater 2: 67-68.

Lydiat, Thomas. 1605. Praelectio astronomica de natura coeli et conditionibus elementorum: tum autem de causis praecipuorum motuum coeli et stellarum, item Disquisitio de origine fontium perennium frigidorum et calidorum. Londini: Excudi curavit Ioannes Bill.

Maffioli, Cesare S. 1994. Out of Galileo. The Science of Waters (1628-1718). Rotterdam: Erasmus Publishing.

Maffioli, Cesare S. 2010. La via delle acque (1500-1700). Appropriazione delle arti e trasformazione delle matematiche. Florence: Olschki.

Magnaghi, Alberto. 1911. Il problema dell'origine delle sorgenti da Cartesio (1639) a Vallisnieri (1725). Rocca San Casciano: Tipografia Licinio Cappelli.

Magruder, Kerry V. 2006. Global visions and the establishment of theories of the Earth. Centaurus 48: 234257.

Magruder, Kerry V. 2008. Understanding a contested print tradition: Bourguet's Mosaic, Platonic and Aristotelian theories of the Earth. The Compass: The Earth-Science Journal of Sigma Gamma Epsilon 81: 9-25.

Majoli, Simone. 1597. Dies caniculares seu Colloquia tria, \& viginti. Romae: ex officina Ioan. Angeli Ruffinelli, typis Aloysij Zannetti.

Mariotte, Edme. 1686. Traite du mouvement des eaux et des autres corps fluides. Paris: Chez Estienne Michallet.

Mariotte, Edme. 1718. The Motion of Water, and Other Fluids. Being a Treatise of Hydrostaticks. London: Printed for J. Senex at the Globe in Salisbury-Court, Fleetstreet, and W. Taylor at the Ship in PaterNoster-Row.

Marsili, Luigi Ferdinando. 1725. Histoire physique de la mer. Amsterdam: Aux dépens de la Compagnie.

Marsili, Luigi Ferdinando. 1930. Osservazioni fisiche intorno al Lago di Garda, detto anticamente Benaco. In: Scritti inediti, 57. Bologna: Zanichelli.

Masini, Romeo. 1931. Antonio Vallisneri e l'origine delle sorgenti. Atti della Reale Accademia Lucchese, Nuova Serie, Tomo I.

Milliet Dechales, Claude François. 1674. Cursus seu mundus mathematicus. Lugduni: Ex officina Anissoniana.

Morello, Nicoletta. 1979. La macchina della Terra, teorie geologiche dal Seicento all'Ottocento. Turin: Loescher.

O’ Malley, John W., Bailey, Gauvin A., Harris, Steven J., and Kennedy, T. Frank (eds.). 2006. The Jesuits II. Cultures, Sciences, and the Arts, 1540-1773. Toronto, Buffalo, and London: University of Toronto Press.

Oldroyd, David R. 1974. Some Neo-Platonic and Stoic influences on mineralogy in the sixteenth and seventeenth centuries. Ambix 21: 128-156.

Oldroyd, David R. 1996. Thinking About the Earth: A History of Ideas in Geology. London: Athlone.

Palissy, Bernard. 1580. Discours admirables de la nature des eaux et fonteines. Paris: Chez M. le Ieune, a l'enseigne du serpent, devant le college de Cambray.

Palissy, Bernard. 1957. The Admirable Discourses of Bernard Palissy, Translated by Aurèle La Rocque. Urbana: University of Illinois Press.

Perrault, Pierre. 1674. De l'origine des fontaines. Paris: Chez Pierre Le Petit, Imprimeur \& Libraire ordinaire du Roy, Rue Saint Jacques a la Croix d'or. 
Perrault, Pierre. 1967. On the Origin of Springs, Translated by Aurèle La Rocque. New York and London: Hafner Publishing.

Plot, Robert. 1685. De origine fontium tentamen philosophicum. Oxonii: E Theatro Sheldoniano.

Plot, Robert. 1686. The Natural History of Stafford-shire. Oxford: Printed at the Theater.

Ramazzini, Bernardino. 1691. De fontium Mutinensium admiranda scaturigine tractatus physicohydrostaticus. Mutinae: Typis Haeredum Suliani Impressorum Ducalium.

Rappaport, Rhoda. 1978. Geology and orthodoxy: the case of Noah's Flood in eighteenth-century thought. The British Journal for the History of Science 11: 1-18.

Rappaport, Rhoda. 1997. When Geologists Were Historians, 1665-1760. Ithaca, NY: Cornell University Press.

Ray, John. 1692. Miscellaneous Discourses Concerning the Dissolution and Changes of the World. London: Printed for Samuel Smith, at the Prince's Arms in St. Paul's Church-Yard.

Roberts, Lissa, Schaffer, Simon and Dear, Peter (eds.). 2007. The Mindful Hand. Inquiry and Invention from the Late Renaissance to Early Industrialisation. Amsterdam: Royal Netherlands Academy of Arts and Sciences.

Rohault, Jacques. 1671. Traite' de physique. Paris: Chez la veuve de Charles Savreux libraire jure, au pied de la tour de Nostre-Dame, a l'enseigne des trois Vertus.

Rosenberg, Gary D. (ed.). 2009. The Revolution in Geology from the Renaissance to the Enlightenment. Boulder: The Geological Society of America.

Rudwick, Martin J. S. 1972. The Meaning of Fossils: Episodes in the History of Paleontology. Chicago: University of Chicago Press.

Rurale, Flavio. 1992. I Gesuiti a Milano. Religione e politica nel secondo Cinquecento. Rome: Bulzoni.

Schott, Gaspar. 1663. Anatomia physico-hydrostatica fontium ac fluminum libris 6 explicata. Herbipoli: Excudit J. Hertz.

Tanga, Mario. 2007. Giacinto Cestoni, i rapporti con Redi e le scienze della vita nel XVII secolo. PhD dissertation, University of Pisa.

Vaccari, Ezio. 2001. Between hydrology and geology: the Italian debate on the origin of springs in the early XVIIIth century. In: OH2, Origin and History of Hydrology. Electronic edition on cd. Dijon: Université de Bourgogne.

Vai, Gian Battista. 2006. Isostasy in Luigi Ferdinando Marsili's manuscripts. In: The Origins of Geology in Italy, edited by Gian Battista Vai and W. Glen E. Caldwell, 95-127. Boulder, CO: The Geological Society of America.

Vallisneri, Antonio. 1715. Lezione Accademica intorno all'Origine delle Fontane. Venezia: Appresso Gio. Gabbriello Ertz.

Vallisneri, Antonio. 1722. Estratto d'alcune Notizie intorno alla Provincia della Garfagnana, cavate dal primo Viaggio Montano del Sig. Antonio Vallisnieri. Supplementi al Giornale de' Letterati d'Italia II: $270-312$.

Vallisneri, Antonio. 1726. Continuazione dell'Estratto d'alcune Notizie intorno alla Garfagnana, cavate dal primo Viaggio Montano del Sig. Antonio Vallisnieri. Supplementi al Giornale de' Letterati d'Italia III: $376-428$.

Van der Meer, Jitse M. and Mandelbrote, Scott (eds.). 2008. Nature and Scripture in the Abrahamic Religions: Up to 1700. Leiden: Brill.

Van Helmont, Jan Baptist. 1682. Opera omnia. Francofurti: Sumptibus J. J. Erythropili.

Wilcox, Donald J. 1987. The Measure of Times Past. Pre-Newtonian Chronologies and the Rhetoric of Relative Time. Chicago and London: University of Chicago Press.

Young, Davis A. 1995. The Biblical Flood. A Case Study of the Church's Response to Extrabiblical Evidence. Grand Rapids, Michigan: William B. Eerdmans Publishing Company; Carlisle: The Paternoster Press. 